\title{
A Morphological Characterization of High Yield Chitin from Periwinkle Shells
}

\author{
Cletus Chiosa Odili* ${ }^{D}$, Oluwashina Philips Gbenebor ${ }^{\circledR}$, Henry Adekola Haffner, Samson Oluropo Adeosun $\mathbb{D}$ \\ University of Lagos, Department of Metallurgical and Materials Engineering, Nigeria \\ *e-mail: chiosa.odili@gmail.com
}

(C) 2021 Authors. This is an open access publication, which can be used, distributed and reproduced in any medium according to the Creative Commons CC-BY 4.0 License requiring that the original work has been properly cited.

Received: 6 May 2021/ Accepted: 6 September 2021/ Published online: 30 September 2021.

This article is published with open access at AGH University of Science and Technology Press.

\begin{abstract}
Research on obtaining chitin from periwinkle shell is scarce due to the very low yield of chitin from this kind of shell. This study reports a method of processing periwinkle shells to obtain high yield, bio-medically suitable chitin. The experiment was designed using IM and $2 \mathrm{M}$ concentrations of $\mathrm{HCl}$ for demineralization and a $1 \mathrm{M} \mathrm{NaOH}$ concentration for deproteinization. FTIR, SEM, XRD and DTA analytical tools were used to characterize the extracted chitin. The FTIR spectral, XRD patterns and SEM analysis, revealed the complete removal of calcium carbonate by the acid concentrations used. The particle-like form of periwinkle shell was transformed to sheet-like fiber and globular-like fiber of $\alpha$-chitin by increasing the concentration of $\mathrm{HCl}$ from1M to $2 \mathrm{M}$ respectively. The crystal size increased from $11.2 \AA$ ( $1 \mathrm{M} \mathrm{HCl})$ to $13.4 \AA$ ( $2 \mathrm{M} \mathrm{HCl})$. The yield of chitin from periwinkle shell also increased from $52 \%$ to $71 \%$ using $1 \mathrm{M}$ and $2 \mathrm{M} \mathrm{HCl}$ respectively. Thus, acid concentrations can be used to alter the structure of chitin with different mechanical properties.
\end{abstract}

Keyword:

periwinkle, polysaccharide, demineralization, deproteinization, morphology

\section{INTRODUCTION}

Chitin is the second most abundant polysaccharide after cellulose [1-3]. Structurally it is similar to cellulose, but differs with the acetamido $\left(-\mathrm{NHCOCH}_{3}\right)$ group positioned at the C2 position [1]. It is estimated to be produced annually as much as cellulose. Chitin is a white, hard nitrogenous polysaccharide found in the exoskeleton and internal structure of invertebrate [1] such as Crustacea and in the cell walls of certain Fungi and Algae [4]. The shells of these animals consist mainly of chitin, calcium carbonate, proteins, lipids and pigments, which are removed via: demineralization (removal of calcium carbonate), deproteinization (removal of protein) and depigmentization (removal of pigments such as carotenoids) [4]. Waste from periwinkles is a major source of environmental pollution and therefore there is a need to harness this waste into functional biomaterials. The new functional biomaterial (chitin), has become a subject of research, due to its potential in various fields like waste water treatment, biomedical, food and pharmaceutical industries [5-7]. Several approaches have been used to extract chitin from periwinkle shells [8]. However, the yield of chitin is relatively very low, around $0.44 \%$ [7]. This study presents a novel procedure for extracting high yield chitin from periwinkle shells with its resultant morphological features.

\section{MATERIALS AND METHODS}

\subsection{Chitin extraction}

Periwinkle shells [Tympanotonus fusatus (L.)] obtained from the Oyingbo market in central Lagos area were scraped free of loose tissues. It was washed in distilled water, dried, ground to $250 \mu \mathrm{m}$ in a ball mill and sieved to $150 \mu \mathrm{m}$. The $\mathrm{HCl}$ (37\% purity) used was bought from chemical vendors at Barriga, Lagos, Nigeria. Demineralization was done at room temperature $\left(30^{\circ} \mathrm{C}\right)$, by soaking the shell in IM and $2 \mathrm{M}$ $\mathrm{HCl}$. The acid was added until gas evolution ceased, and for each of the concentrations. The demineralized sample was washed with distilled water to neutrality ( $\mathrm{pH} 7.0$ ), filtered and dried in an oven at $90^{\circ} \mathrm{C}$ for 6 hours. Deproteinization was done by soaking demineralized sample in $1 \mathrm{M} \mathrm{NaOH}$ in a beaker and heated for 4 hours at $99.9^{\circ} \mathrm{C}$. Deproteinized sample was then decanted and soaked in a fresh set of $1 \mathrm{M}$ $\mathrm{NaOH}$ solution at a room temperature for 24 hour for effective protein removal. The samples were then washed to neutrality, filtered and dried at $80^{\circ} \mathrm{C}$ before characterization. 


\subsection{Fourier transform infrared spectroscopy (FTIR)}

A SHHIMADZU FTIR-8400 S spectrometer located at Redeemers University, Ede, Nigeria was used to carry out FTIR spectra of samples in transmission mode. Ten milligrams of fine samples were dispersed in a matrix of $\mathrm{KBr}(500 \mathrm{mg})$, followed by compression at 22-30 MPa to form pellets. The transmittance measurements were carried out in the range $400-4000 \mathrm{~cm}^{-1}$ at a resolution of $4 \mathrm{~cm}^{-1}$. Acetylation degree (DA) was measured from the FTIR spectroscopy.

The DA was calculated using Equation (1) [9]:

$$
D A=[(A 1650 / A 3450) \times 100 / 1.33]
$$

where:

$$
\begin{aligned}
& A 1650 \text { - the absorbance of amide I vibration; } \\
& A 3450 \text { - the absorbance of } \mathrm{OH} \text { vibration; } \\
& 1.33 \text { - a factor that represents the ratio for fully N-acety- } \\
& \text { lated chitin. }
\end{aligned}
$$

\subsection{XRD analysis}

The X-ray diffractometry measurements were performed on an EMPYREAN XRD-6000 diffractometer using CuKa radiation ( $\mathrm{l}=1.540598 \mathrm{~nm}$, Ni-filter) at $40 \mathrm{kV}, 30 \mathrm{~mA}$. The samples without preferred orientations were scanned in steps of 0.026261 in the $2 \theta$ from 4.99 to 75 using a count time of $29.7 \mathrm{~s}$ per step.

Crystallinity index (Crl) for chitin was calculated using Equation (2) [10]:

$$
\operatorname{Crl}(\%)=[(I c / I c+I a)] \times 100
$$

where Ic and Ia represents the intensities of the crystalline and amorphous region respectively.

Crystalline size normal to hkl plane (Dhkl) was calculated from the full width at half height of the source curve using Equation (3) [11]:

$$
D h k l=\frac{\mathrm{K} \lambda}{\beta \cos \theta}
$$

where:

$$
\begin{aligned}
& \text { K - a constant (indicative of crystallite perfection and } \\
& \text { is assumed to be } 1 \text { ); } \\
& \lambda \text { - the wave length of incident radiation }(1.5406 \AA) \text {; } \\
& \beta \text { - the width of the crystalline peak at half height, rad; } \\
& \theta \text { - the diffraction angle corresponding to the crys- } \\
& \text { talline peak, deg. }
\end{aligned}
$$

\subsection{Scanning electron microscopy (SEM)}

The sample micrographs were produced via a scanning electron microscopy model Phenom Eindhoven, Netherlands. It works with an electron intensity beam of $15 \mathrm{kV}$, while the samples to be observed were usually mounted on a conductive carbon imprint left by adhesive tape. This is usually prepared by placing the samples on the circular holder and coated for $5 \mathrm{~min}$ to enable it to conduct electricity.

\subsection{Differential thermal analysis (DTA)}

The Diffraction Thermal Analysis measurements were carried using a NETZSCH DTA 404 PC DTA analyzer model at the Centre for Energy Research and Development, Obafemi Awolowo University Ile-Ife, Nigeria. A $5 \mathrm{mg}$ sample of mass was combusted in DTA/TG crucible $\mathrm{Al}_{2} \mathrm{O}_{3}$, within a temperature range of $0-1000^{\circ} \mathrm{C}$.

\subsection{Chitin yield [\%] determination}

Chitin yield was calculated from the XRD intensity, using the Equation (4):

$$
\text { Yield }(\%)=[I v-I c h / I v] \times 100
$$

where:

$$
\begin{aligned}
& I V \text { - the intensity of chitin in virgin periwinkle shells; } \\
& I c h \text { - the intensity of chitin in fully treated chitin. }
\end{aligned}
$$

\section{RESULTS AND DISCUSSION}

\subsection{Functional groups of periwinkle shells and chitin}

Different absorption bands were recorded in the range of 4000 to $500 \mathrm{~cm}^{-1}$ in the FTIR spectral of the periwinkle shells. The spectra revealed that different functional groups exist on the surface of the shell. The spectral of virgin periwinkle (Fig. 1) are $1798 \mathrm{~cm}^{-1}, 1420-1430 \mathrm{~cm}^{-1}, 876, \mathrm{~cm}^{-1}$ which are for calcite $[7,12]$.

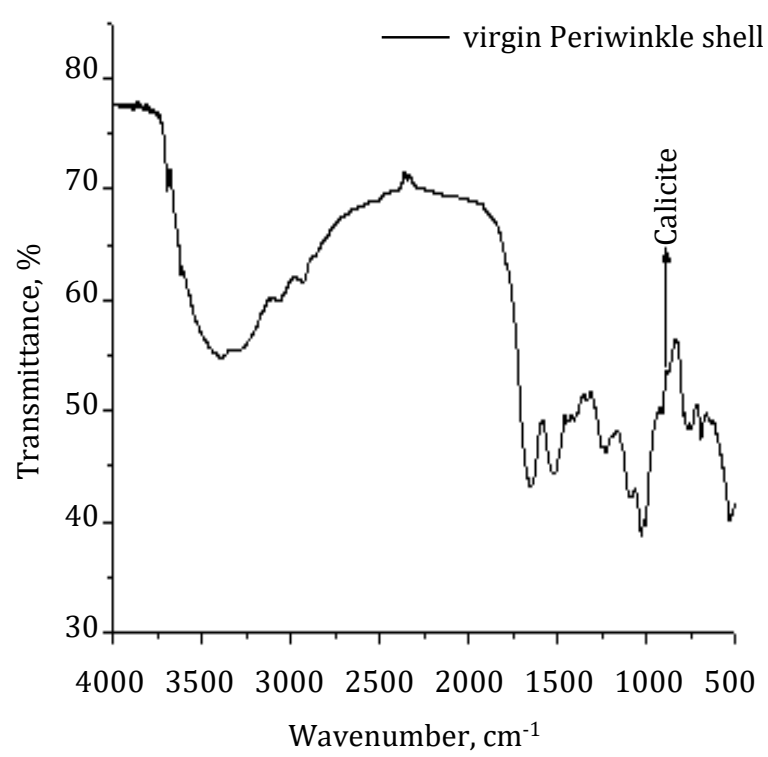

Fig. 1. FTIR spectra of virgin periwinkle shell

Figure 2 represent the spectra of chitin. The peak located at $3421.46 \mathrm{~cm}^{-1}$ could be assigned to $\mathrm{OH}$ group of the water molecule. While the peaks at $2923.30 \mathrm{~cm}^{-1}$ is assigned to $\mathrm{C}-\mathrm{H}$ stretching vibration of aliphatic hydrocarbon. The peak at $1653.19 \mathrm{~cm}^{-1}$ is attributed to the axial strain of $\mathrm{C}=0$ present in chitin, which represent amide I, absorption peak at $1531 \mathrm{~cm}^{-1}$ correspond to the mixture of the two vibrational modes $\mathrm{NH}$ 
in the plane and $\mathrm{C}-\mathrm{H}$ stretching called amide II. A peak around $2923.30 \mathrm{~cm}^{-1}$ was also observed and is attributed to $\mathrm{CH}$ stretching. The peak at $1017.88 \mathrm{~cm}^{-1}$ is assigned to $\mathrm{C}-\mathrm{O}-\mathrm{C}$ group. From Figure 2 it can been seen that the spectra obtained here compare well with the standard spectra of chitin found in literature [7, 13]. The most important signals for the spectrum of chitin peak are $1653.19 \mathrm{~cm}^{-1}$ and $1531.88 \mathrm{~cm}^{-1}$ stretches of amides I and II that are characteristics of $\alpha$-chitin [7]. For the purpose of comparison, acid treated and fully treated periwinkle shell were reported (Fig. 2). There is a slight structural difference between the spectra of demineralized periwinkle shell and that which was demineralized, followed by deproteinization. However, the intensity of peak for $2 \mathrm{M}$ is higher compared with $1 \mathrm{M}$ acid. The degree of acetylation for $1 \mathrm{M}$ and $2 \mathrm{M} \mathrm{HCl}$ are 73 and 64 respectively. Thus, increased concentrations of acid lead to a decrease in the degree of acetylation, an observation earlier made by [7].

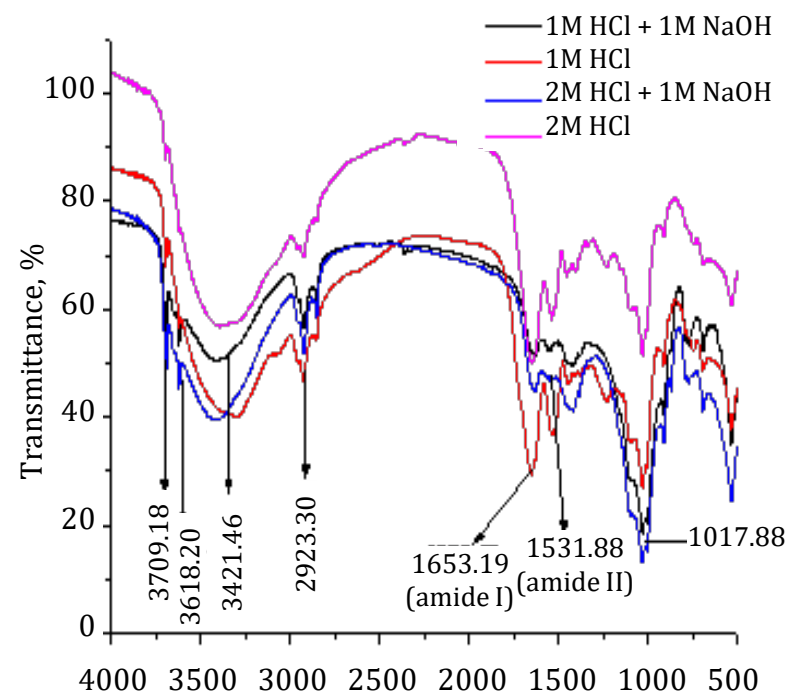

Wavenumber, $\mathrm{cm}^{-1}$

Fig. 2. FTIR spectra of acid treated and fully treated sample

\subsection{Morphology of the periwinkle and extracted chitin samples}

Figure 3 shows the morphology of the virgin periwinkle shell, an acid treated and a fully treated periwinkle shell. Calcite $\left(\mathrm{CaCO}_{3}\right)$, which is the most dominant in the composition of periwinkle shell, was observed in the virgin periwinkle shell. The morphology showed particle-like substances in the virgin periwinkle shell, which is an indication of the presence of calcium carbonate. After treatment with acid, the calcite disappeared as revealed by the micrograph of the treated and fully treated shells. The particle-like rough surfaces in the raw periwinkle shell were smoothened by the acid treatment. The surface roughness of $\alpha$-chitin has been associated with a low degree of acetylation [7], which implies that increase in acid concentration induces partial deacetylation, as the smoothness of the surface increased with the rise in acid concentration. A similar morphology had been reported for $\alpha$-chitin from periwinkle by [7]. The plate-like fiber turned to a globular structure with $2 \mathrm{M}$ in fully treated chitin. a)

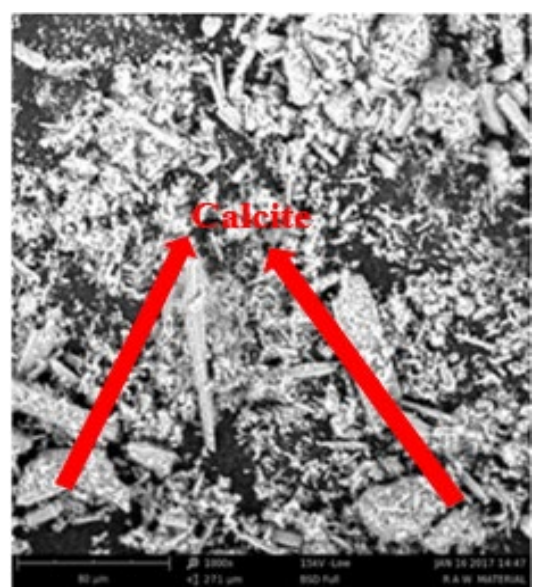

b)

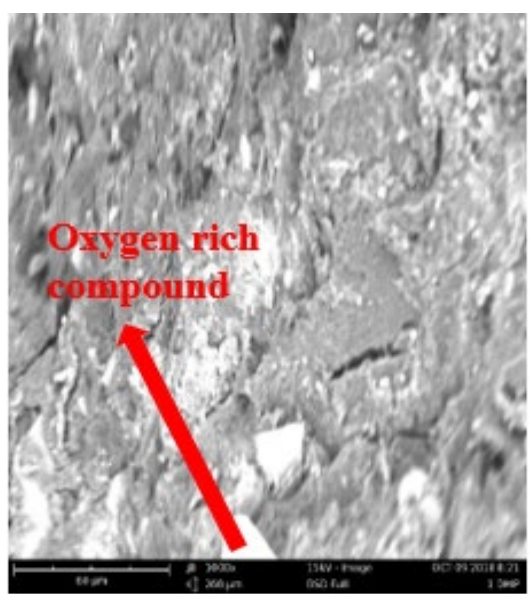

c)

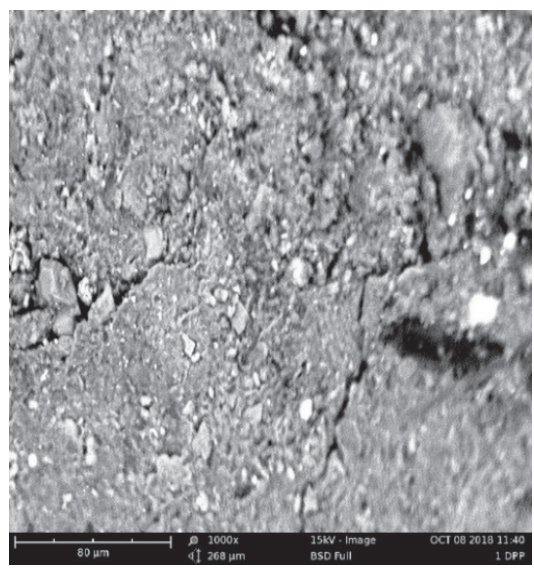

d)

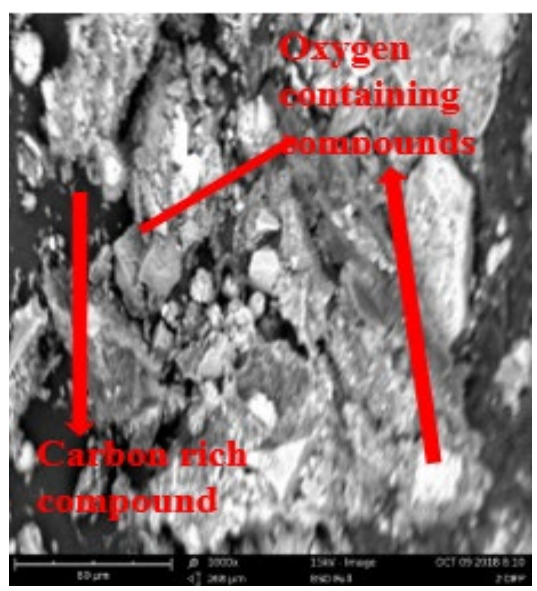

Fig. 3. SEM Image of periwinkle shell: a) virgin; b) $1 \mathrm{M} \mathrm{HCl}$ acid treated; c) $1 \mathrm{M} \mathrm{HCl}+1 \mathrm{M} \mathrm{NaOH}$ fully treated; d) $2 \mathrm{M} \mathrm{HCl}+1 \mathrm{M} \mathrm{NaOH}$ fully treated 


\subsection{Crystallinity behavior of periwinkle shell extract}

The XRD pattern of periwinkle shell is displayed in Figure 4. The virgin periwinkle shell showed crystalline diffraction peaks of calcite at $27.07^{\circ}, 35.84^{\circ}, 42.72^{\circ}$ [14]. After acid treatment these peaks disappeared, confirming the complete removal of $\mathrm{CaCO}_{3}$. The XRD patterns of acid treated periwinkle shell (Fig. 5) showed two sharp peaks at $2 \theta=2^{\circ}$ and $26^{\circ}$. However, as $\mathrm{HCl}$ concentration increased from $1 \mathrm{M}$ to $2 \mathrm{M}$, the intensity of the peaks reduced. This phenomenon was also reported by [7]. This might be due to partial deacetylation that occurred with the use of higher acid concentration. The fully treated shell, showed sharp crystalline reflections at 20.0 and 26.7 but with growth of peaks at $2 \theta=26.7^{\circ}, 20.0^{\circ}$, $29.0^{\circ}, 3^{\circ}, 39^{\circ}, 42^{\circ}$ and $47^{\circ}$, compared with acid only treated shell. The peaks at 26.7 and 20.6 is a typical reflection of partially deacetylated chitin, which correspond to the prominent peak of $\alpha$-chitin [15]. The peak at $20.1^{\circ}$ is in the range reported by [7] corresponding to the Chitosan peak. Thus, the chitin extracted in this work is a mixture of Chitin and Chitosan. The $\mathrm{Crl}(\%)$ for fully treated $1 \mathrm{M}$ and $2 \mathrm{M}$ are 84 and $73 \%$ respectively. The effect of acid concentration on crystallinity, crystal size and percentage yield, can be seen in Table 1 . The crystallinity decreases from $84 \%$ to $73 \%$ as acid concentration increases from $1 \mathrm{M}$ to $2 \mathrm{M}$. This trend was also reported by [7]. The crystal size at $2 \theta=26^{\circ}$ reduced from $16 \AA$ to $11.2 \AA$ as the concentration increased from $1 \mathrm{M}$ of $\mathrm{HCl}$ acid to $2 \mathrm{M} \mathrm{HCl}$ for demineralization. Conversely, after deproteinization, the crystal size increases from $11 \AA$ to $13 \AA$ for $1 \mathrm{M} \mathrm{HCl}$ and $2 \mathrm{M}$ $\mathrm{HCl}$ respectively. It was also observed that chitin yield increased from $52 \%$ to $71 \%$ as the concentration of acid ( $\mathrm{HCl}$ ) increased from $1 \mathrm{M}$ to $2 \mathrm{M}$.

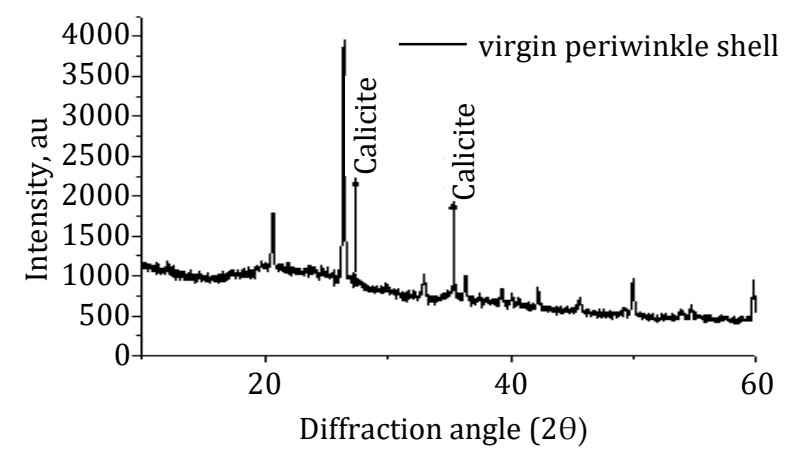

Fig. 4. XRD spectra of virgin periwinkle shell

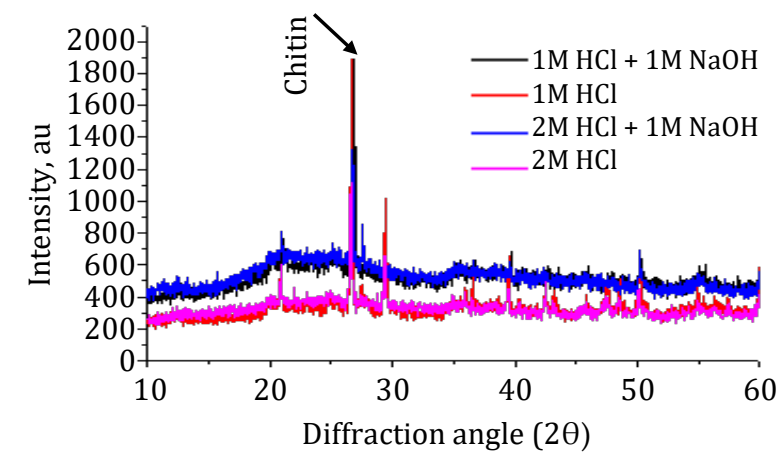

Fig. 5. XRD spectra of acid treated and fully treated periwinkle shell extract
Table 1

Extracted chitin crystallinity index, crystal size and yield

\begin{tabular}{cccc}
\hline $\begin{array}{c}\text { HCl molar } \\
\text { concentration }\end{array}$ & $\begin{array}{c}\text { Crystallinity } \\
\text { index } \\
{[\%]}\end{array}$ & $\begin{array}{c}\text { Crystal } \\
\text { size } \\
{[\AA]}\end{array}$ & $\begin{array}{c}\text { Chitin } \\
\text { yield } \\
{[\%]}\end{array}$ \\
\hline $1 \mathrm{M} \mathrm{HCl}$ & 84 & 11.2 & 52 \\
\hline $2 \mathrm{M} \mathrm{HCl}$ & 73 & 13.4 & 71 \\
\hline
\end{tabular}

\subsection{Thermal analysis of periwinkle shells and chitin extract}

The DTA thermogram displayed in Figure 6 shows a peak at $91.99^{\circ} \mathrm{C}$ representing the loss of water molecules, which varied between -4.3 to $-7.49 \mathrm{mg}$ weight loss. The peak is more pronounced with $2 \mathrm{M}$ of $\mathrm{HCl}$ for fully treated and acid treated in comparison with $1 \mathrm{M} \mathrm{HCl}$ for acid treated and fully treated. Earlier researchers reported the loss of water molecules from chitin while using TGA, to evaluate the decomposition of chitin [7]. The peak between $355.93^{\circ} \mathrm{C}$ and $597.89^{\circ} \mathrm{C}$, with a weight loss from -17 to $-21 \mathrm{mg}$, shows the degradation of the saccharide structure of the molecule and the decomposition of the acetylated units of chitin [7]. The peak position for the two concentrations was the same for fully treated samples, but a shift in the peak occurred $\left(432.9^{\circ} \mathrm{C}\right)$ for the acid treated ones.

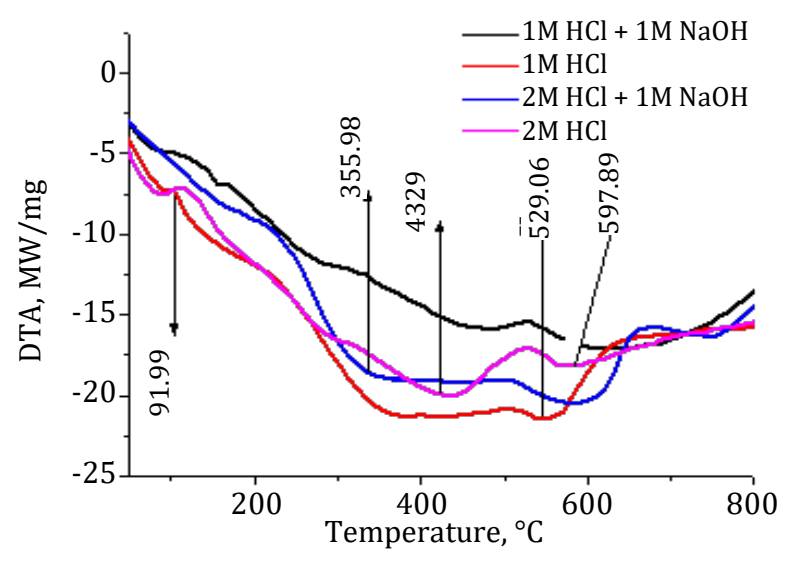

Fig. 6. DTA plot of acid treated and fully treated periwinkle shell

\section{CONCLUSION}

Chitin has been successfully extracted from periwinkle shells. The study showed that calcium carbonate $\left(\mathrm{CaCO}_{3}\right)$ can be completely eliminated from periwinkle shells using $1 \mathrm{M}$ and $2 \mathrm{M}$ of $\mathrm{HCl}$ for demineralization. The XRD revealed the important peaks of chitin at $2 \theta=26.7^{\circ}$ and $20.6^{\circ}$, which confirms chitin extraction using $1 \mathrm{M} / 2 \mathrm{M}$ of $\mathrm{HCl}$ and $1 \mathrm{M}$ of $\mathrm{NaOH}$. The crystallinity index was observed to be inversely related to the concentration of acid. The crystal size of chitin increased from $11 \AA$ to $13 \AA$, with the increase in the concentration of $\mathrm{HCl}$ from $1 \mathrm{M}$ to $2 \mathrm{M}$. A higher yield of chitin $(71 \%)$ was observed from $2 \mathrm{M}$ of $\mathrm{HCl}$ compare to $52 \%$ obtained using $1 \mathrm{M}$. The chitin was noted to decompose between $355.93^{\circ} \mathrm{C}$ and $597.89^{\circ} \mathrm{C}$. This study established that the morphology of the sample was affected by the concentration of acid used. 


\section{REFERENCES}

[1] Dutta P.K., Dutta J. \& Tripathi V.S. (2004). Chitin and chitosan: Chemistry, properties and applications. Journal of Scientific and Industrial Research, 63, 20-31.

[2] Ocloo F.C.K., Quayson E.T., Adu-Gyamfi A., Quarcoo E.A., Asare D., Serfor-Armah Y. \& Woode B.K. (2011). Physiochemical and functional characteristics of radiation-processed shrimp chitosan. Radiation Physics and Chemistry, 80(7), 837-841. Doi: https:// doi.org/10.1016/j.radphyschem.2011.03.005.

[3] Younes I. \& Rinaudo M. (2015). Chitin and chitosan from marine sources. Structure, properties and application. Marine Drugs, 13(3), 1133-1174. Doi: https://doi.org/10.3390/md13031133.

[4] Mohammed M.H., Williams P.A. \& Tverezovskaya O. (2013). Extraction of chitin from prawn shells and conversion to low molecular mass chitosan. Food Hydrocolloids, 31(2), 166-171. Doi: https://doi.org/10.1016/j.foodhyd.2012.10.021.

[5] Jayakumar R., Prabaharan M., Nair S.V. \& Tamura H. (2010). Novel chitin and chitosan nanofibers in biomedical applications. Biotechnology Advances, 28(1), 142-150. Doi: https:// doi.org/10.1016/j.biotechadv.2009.11.001.

[6] Kurita K. (2006). Chitin and chitosan: Functional biopolymers from marine crustaceans. Marine Biotechnology, 8(3), 203-226. Doi: https://doi.org/10.1007/s10126-005-0097-5.

[7] Isa M.T., Ameh A.O., Gabriel J.O. \& Adama K.K. (2012). Extraction and characterization of chitin from Nigerian sources. Leonardo Electronic Journal of Practices and Technologies, 21(11), 73-81.

[8] Gbenebor O.P., Akpan E.I. \& Adeosun S.O. (2017). Thermal, structural and acetylation behavior of snail and periwinkle shells chitin. Progress in Biomaterials, 6(3), 97-111. Doi: https://doi. org/10.1007/s40204-017-0070-1.
[9] Kaya M., Seyyar O., Baran T. \& Türkeș T. (2014). Bat guano as new and attractive chitin and chitosan source. Frontiers in Zoology, 14(59). Doi: https://doi.org/10.1186/s12983-014-0059-8.

[10] Juárez-de la Rosa B.A., Quintana P., Ardisson P.-L., Yáñez-Limón J.M. \& Alvarado-Gil J.J. (2012). Effects of thermal treatment on the structure of two black coral species chitinous exoskeleton. Journal of Materials Science, 47(2), 990-998. Doi: https://doi. org/10.1007/s10853-011-5878-9.

[11] Wang Y., Chang Y., Yu L., Zhang C., Xu X., Xue Y., Li Z. \& Xue C. (2013). Crystalline structure and thermal property characterization of chitin from Antarctic krill (Euphausia superba). Carbohydrate Polymers, 92(1), 90-97. Doi: https://doi.org/10.1016/ j.carbpol.2012.09.084.

[12] Shyhlong H.W. (2013). Synthesis and characterization of Chitosan from Shrimp Shell. University of Tunku Abdul Rahman, Petaling Jaya [BSc. thesis].

[13] Zaku S.G., Emmanuel S.A., Aguzue O.C. \& Thomas S.A. (2011). Extraction and characterization of chitin, a functional biopolymer obtained from scales of common carp fish (Cyprinus carpiol I.): A lesser known source. African Journal of Food Science, 5(8), 478-483. Retrieved from: http://www.academicjournals.org/ ajfs.

[14] Heredia A., Aguilar-Franco M., Magana C., Flora C., Valazquez R., Schaffer T.E., Bucio L. \& Basiuk V.A. (2007). Structure and interactions of calcite spherulites with $\alpha$-chitin in the brown shrimp (Penaeus aztecus) shell. Materials Science and Engineering: $C$ 27(1), 8-13. Doi: https://doi.org/10.1016/j.msec.2005.11.003.

[15] Liu T., Li B., Zheng X., Liang S., Song X., Zhu B. Kennedy J.F. \& Xia J. (2010). Effects of freezing on the condensed state structure of chitin in alkaline solution. Carbohydrate Polymers, 82(3), 753-760. Doi: https://doi.org/10.1016/j.carbpol.2010.05.047. 